\title{
Surface Roughness Optimization in Drilling Process Using Response Surface Method (RSM)
}

\author{
Mohd Amran ${ }^{a}$, Siti Salmaha, Mohd Sanusia , Mohd Yuhazria, Noraiham Mohamada, Mohd Asyadi' Azamª, Zulkeflee Abdullaha, Effendi \\ Mohamada
}

${ }^{a}$ Faculty of Manufacturing Engineering, Universiti Teknikal Malaysia Melaka, Hang Tuah Jaya,76100 Durian Tunggal, Melaka, Malaysia

*Corresponding author: mohdamran@utem.edu.my

\section{Article history}

Received : 20 December 2013

Received in revised form :

10 January 2014

Accepted :14 January 2014

Graphical abstract

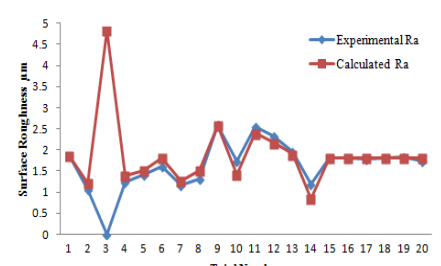

TrialNumber

\begin{abstract}
This paper presents the effect of drilling parameters on surface roughness and surface appearance by applying response surface method (RSM). The mathematical model for correlating the interactions of drilling parameters such as spindle speed, feed rate and drill diameter on surface roughness was developed. RSM methodology was used as it is a technique that most practical and effective way to develop a mathematical model. In addition, this method also can reduce trial and error in experiment. Since the number of factors are three; spindle speed, feed rate and drill diameter, by applying RSM the total numbers of experiment involved are 20 experimental observations. From the experimental result, it is found that the minimum surface roughness on the hole was $1.06 \mu \mathrm{m}$ from combination of $2000 \mathrm{rpm}$ spindle speed, $78 \mathrm{~mm} / \mathrm{min}$ feed rate and $2.5 \mathrm{~mm}$ drill diameter. While the maximum surface roughness $2.59 \mu \mathrm{m}$ was the combination of $250 \mathrm{rpm}$ spindle speed, $153 \mathrm{~mm} / \mathrm{min}$ feed rate and $3.5 \mathrm{~mm}$ drill diameter. A mathematical equation was developed with percentage of error are $0 \%$ to $29 \%$. Thus, from the result we understand that to find the smooth surface in drilling process, it needs higher spindle speed with lower feed rate and smaller diameter.
\end{abstract}

Keywords: Drilling process; machining parameters; surface roughness; response surface method (RSM)

\section{Abstrak}

Kertas kerja ini mengkaji kesan parameter penggerudian terhadap kekasaran permukaan dan keadaan permukaan dengan menggunakan kaedah tindak balas permukaan (KTP). Model matematik untuk menghubungkaitkan interaksi parameter penggerudian seperti kelajuan gelendong, kadar suapan dan gerudi kepada kekasaran permukaan telah dihasilkan. KTP digunakan kerana ia adalah satu teknik yang paling praktikal dan berkesan untuk membangunkan satu model matematik. Di samping itu, kaedah ini juga boleh mengurangkan percubaan dan kesilapan dalam eksperimen. Oleh kerana tiga faktor iaitu; kelajuan gelendong, kadar suapan dan gerudi diameter, dengan menggunakan KTP jumlah eksperimen melibatkan 20 pemerhatian eksperimen. Dari keputusan eksperimen, didapati bahawa kekasaran permukaan minimum pada lubang adalah $1.06 \mu \mathrm{m}$ dari gabungan kelajuan $2000 \mathrm{rpm}$ gelendong, kadar suapan $78 \mathrm{~mm} / \mathrm{min}$ dan $2.5 \mathrm{~mm}$ garispusat gerudi. Manakala permukaan kekasaran maksimum $2.59 \mu \mathrm{m}$ adalah gabungan kelajuan $250 \mathrm{rpm}$ gelendong, kadar suapan $153 \mathrm{~mm} / \mathrm{min}$ dan $3.5 \mathrm{~mm}$ garispusat gerudi. Satu persamaan matematik telah dibangunkan dengan peratusan ralat $0 \%$ hingga $29 \%$. Oleh itu, dari hasil yang kita faham bahawa untuk mencari permukaan licin dalam proses penggerudian, ia memerlukan gelendong kelajuan yang lebih tinggi dengan kadar suapan yang lebih rendah dan garis pusat yang lebih kecil.

Kata kunci: Proses Penggerudian; permesinan parameter; kekasaran permukaan; kaedah tindak balas permukaan

\subsection{INTRODUCTION}

Drilling is one of the most important machining processes for making hole or enlarging a hole in an object by forcing a rotating tool called drill [1]. Approximately $75 \%$ of all metal cutting process involves drilling operation [2]. The cost of hole making is among the highest cost in automotive engine production [3]. Quality is one of the important aspects in drilling industries. Surface roughness and hole appearance are among the important indicator that related to quality in machining processes [4-5]. 
Parameters plays a critical role in improving the surface roughness and hole appearance in drilling process. In order to study the relationship between drilling process parameters and surface roughness, a systematically approach, the design of experiments (DOE); response surface method (RSM) can be used effectively.

RSM is a collection of mathematical and statistical techniques useful for the modelling and analysis of problems in which a response of interest is influenced by several variables [67]. The main advantage of RSM is the reduced number of experimental trials needed to evaluate multiples parameters and their interaction [8]. By applying RSM, mathematical model will be developed. The mathematical model will help to study the direct and interaction effect of each parameter on the responses.

Since drilling process is one of the most important process in industry, several researchers were studied in order to optimize the quality in this process. Mohan et al. investigated the effect of cutting speed, feed rate, drill size and specimen thickness on cutting force and torque when drilling of glass fibre polyester reinforced composites [9]. Khashaba et al. [10] presented a story of the influence of drilling parameters (cutting speed and feed rate) on the required cutting forces, torques and delamination that occurs at drill entrance and exit in drilling composites with different fibre volume fractions. Tsao and Hocheng [11] investigated a prediction and evaluation of delamination factor in use of twist drill, candle stick drill and saw drill. The objective of their study was to establish a correlation between feed rate, spindle speed and drill diameter. Rao et al. [12] presented a comprehensive study of delamination in use of various drill types, three different feed rate and spindle speeds. Kilickap [13] investigated the influence of the cutting parameters, such as cutting speed and feed rate, and point angle on delamination produced when drilling a glass-fibre reinforced plastic (GFRP) composite. Further, Onwobolo investigated about the correlating the interactions of some drilling control parameters such as speed, feed rate and drill diameter and their effects on some responses such as axial force and torque acting on the cutting tool during drilling by means of response surface method [14].

In this study, the effects of parameters such as spindle speed, feed rate and drill diameter are investigated onto the surface integrity in term of surface roughness and appearance observation of hole by applying a response surface method (RSM) and analysis of variance (ANOVA).

\subsection{EXPERIMENTAL PROCEDURES}

\subsection{Machine, Drill bit and Materials}

In this project, the drilling process was carried out using Mazak 630-5x CNC vertical milling machine. Surface roughness of the specimen was measured by Mitutoyo portable surface roughness tester SJ-301. Then, portable microscope was used to capture the image of the hole. The cutting tool used was twist drill high speed steel (HSS) with diameter $1.5 \mathrm{~mm}, 2.5 \mathrm{~mm}, 3.5 \mathrm{~mm}, 5 \mathrm{~mm}$ and $5.5 \mathrm{~mm}$. General specification for twist drill is shown in Table 1. The drilling performance tests were conducted on Aluminium alloy bars. There were combinations of two pieces of work piece. The workpiece material used has a dimension of $150 \mathrm{~mm}$ length, $50 \mathrm{~mm}$ width and $9 \mathrm{~mm}$ thickness on each workpiece.
Table 1 Twist drill specification

\begin{tabular}{cc}
\hline Drill Bit & HSS twist drill \\
\hline Drill Bit Diameter(mm) & $1.5,2.5,3.5,5,5.5$ \\
Depth of Cut (mm) & 10 \\
Point Angle $\left({ }^{\circ}\right)$ & 118 to 135 \\
Lip-Relief Angle $\left({ }^{\circ}\right)$ & 7 to 15 \\
Chisel Edge Angle $\left(^{\circ}\right)$ & 125 to 135 \\
Helix Angle $\left({ }^{\circ}\right)$ & 15 to 30 \\
\hline
\end{tabular}

\subsection{Experimental Matrix}

In this experiment, three factors are being studied. There are spindle speed, feed rate and drill diameter. Their low and high levels for each factor are given in Table 2. The factors and levels were substitute into Microsoft Design Expert version 6.0 to form design matrix that were used in experiment. The design matrix showed all possible combinations of high and low levels for each input factor.

Central composite design (CCD) is the most common RSM design used for process modelling. A CCD has three groups of design points, namely two-level factorial or fractional design points, axial point and centre points. Two level factorial part consist of all possible combinations of $(+1)$ and (-1). While the axial point have all of the factors set to mid-point with the value of $+/-\alpha$. Centre point is implied by point with set to $(0,0)[15]$. In this experiment, 6 center points were used and the center point for spindle speed is $1135 \mathrm{rpm}$, feed rate $153 \mathrm{~mm} / \mathrm{min}$ and drill diameter $3.5 \mathrm{~mm}$. Center points were repeated 6 times to get a good estimation of experimental error (pure error). So, this experiment consists of 8 two level factorial points, 6 axial points and 6 centre point making a total of experiments are 20 .

Table 2 Process control parameters and limitation

\begin{tabular}{|c|c|c|c|}
\hline \multirow{2}{*}{ Factors } & \multirow{2}{*}{ Parameters } & \multicolumn{2}{|c|}{ Limit } \\
\hline & & -1 & +1 \\
\hline A & $\begin{array}{l}\text { Spindle Speed } \\
\text { (rpm) }\end{array}$ & 270 & 2000 \\
\hline B & $\begin{array}{l}\text { Feed Rate } \\
(\mathrm{mm} / \mathrm{min})\end{array}$ & 78 & 228 \\
\hline $\mathrm{C}$ & $\begin{array}{l}\text { Drill Diameter } \\
(\mathrm{mm})\end{array}$ & 2.5 & 5.0 \\
\hline
\end{tabular}

By applying RSM type central composite design, the planning matrix contains the value beyond the range to allow estimation of curvature. The lower limit for low (-1) was added for spindle speed $(250 \mathrm{rpm})$, feed rate $(27 \mathrm{~mm} / \mathrm{min})$ and drill diameter $(1.5 \mathrm{~mm})$. While the upper limit for $(+1)$ was added for spindle speed $(2590 \mathrm{rpm})$, feed rate $(279 \mathrm{~mm} / \mathrm{min})$ and drill diameter $(5.5 \mathrm{~mm})$

\subsection{Sample Preparation}

Figure 1 shows the sample of the workpiece prepared by milling machine. The raw material size was $610 \mathrm{~mm}$ x $55 \mathrm{~mm}$ x $10 \mathrm{~mm}$. Then, the raw material was cut into 4 pieces by using band saw machine. Each part was cut into $151 \mathrm{~mm}$ x $55 \mathrm{~mm}$ x $10 \mathrm{~mm}$. Then, each workpiece was carried out by facing process to size $150 \mathrm{~mm} \times 50 \mathrm{~mm} \times 9 \mathrm{~mm}$. The purpose of facing process is to 
make sure the surface become smooth. Smooth surface allows the work piece attach properly and fixed by cap screw neatly. The workpieces were fixed by M6 cap screw and inserted by guide pin for reference purposes.

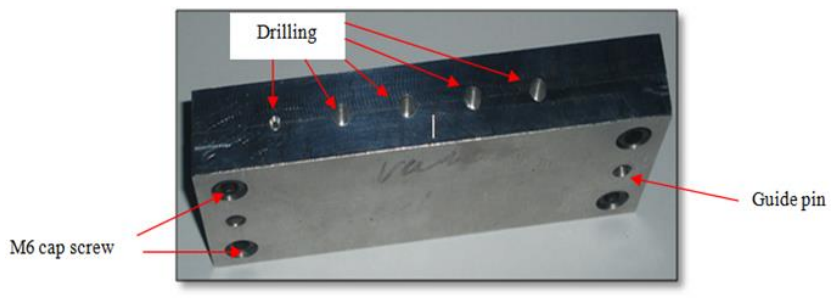

Figure 1 Drilling sample for drilling process

\subsection{RESULTS AND DISCUSSION}

\subsection{Experimental Result}

The effect of drilling parameters, i.e., spindle speed, feed rate and drill diameter, on the surface roughness by conducting experiments is shown in Table 3. From the result, it shows that the minimum of surface roughness is $1.06 \mu \mathrm{m}$ in specimen number 2 and the maximum is $2.59 \mu \mathrm{m}$ in specimen number 9 . Figure 2 and Figure 3 shows comparison appearance of observation for specimen no 2 and specimen number 9 as the minimum and maximum surface roughness.

All run samples were finish drilling process; accept for the specimen number 3 due to drill fracture, and then the surface roughness cannot be measure. This because of the tool was break. Run no 3 is the combination of spindle speed at $270 \mathrm{rpm}$, feed rate $228 \mathrm{~mm} / \mathrm{min}$ and drill diameter 2.5. The spindle speed is low and the feed rate is high. The higher feed rate will produce excessive chip loading. The excessive chip loading will be clog causing the cutting edges to fracture. Therefore, the sample for run number 3 was break. Figure 4 shows the appearance of observation for specimen number 3 .

Generally, higher spindle speed with lower feed rate and smaller diameter will decrease the surface roughness. Higher spindle speed helps remove excess heat rapidly and also ejects the chips produced during drilling process. The higher feed rate will produce excessive chip loading. The excessive chip loading will be clog causing the cutting edges to fracture. So, because of that reason, the higher spindle speed with lower feed rate will produce lower surface roughness.

Table 3 Experimental result for surface roughness

\begin{tabular}{|c|c|c|c|c|}
\hline No. & $\begin{array}{c}\text { Factor A } \\
\text { Spindle Speed (N) } \\
(\mathbf{r p m})\end{array}$ & $\begin{array}{c}\text { Factor B } \\
\text { Feed Rate (f) } \\
(\mathbf{m m} / \mathbf{m i n})\end{array}$ & $\begin{array}{c}\text { Factor C } \\
\text { Drill Diameter (d) } \\
(\mathbf{m m})\end{array}$ & $\begin{array}{c}\text { Surface Roughness } \\
(\mu \mathrm{m})\end{array}$ \\
\hline 1 & 270 & 78 & 2.5 & 1.86 \\
\hline 2 & 2000 & 78 & 2.5 & 1.06 \\
\hline 3 & 270 & 228 & 2.5 & $\begin{array}{l}\text { Cannot measure (drill } \\
\text { broken) }\end{array}$ \\
\hline 4 & 2000 & 228 & 2.5 & 1.24 \\
\hline 5 & 270 & 78 & 5 & 1.42 \\
\hline 6 & 2000 & 78 & 5 & 1.62 \\
\hline 7 & 270 & 228 & 5 & 1.17 \\
\hline 8 & 2000 & 228 & 5 & 1.31 \\
\hline 9 & 250 & 153 & 3.5 & 2.59 \\
\hline 10 & 2590 & 153 & 3.5 & 1.74 \\
\hline 11 & 1135 & 27 & 3.5 & 2.56 \\
\hline 12 & 1135 & 279 & 3.5 & 2.33 \\
\hline 13 & 1135 & 153 & 1.5 & 1.97 \\
\hline 14 & 1135 & 153 & 5.5 & 1.19 \\
\hline 15 & 1135 & 153 & 3.5 & 1.82 \\
\hline 16 & 1135 & 153 & 3.5 & 1.8 \\
\hline 17 & 1135 & 153 & 3.5 & 1.79 \\
\hline 18 & 1135 & 153 & 3.5 & 1.8 \\
\hline 19 & 1135 & 153 & 3.5 & 1.83 \\
\hline 20 & 1135 & 153 & 3.5 & 1.73 \\
\hline
\end{tabular}




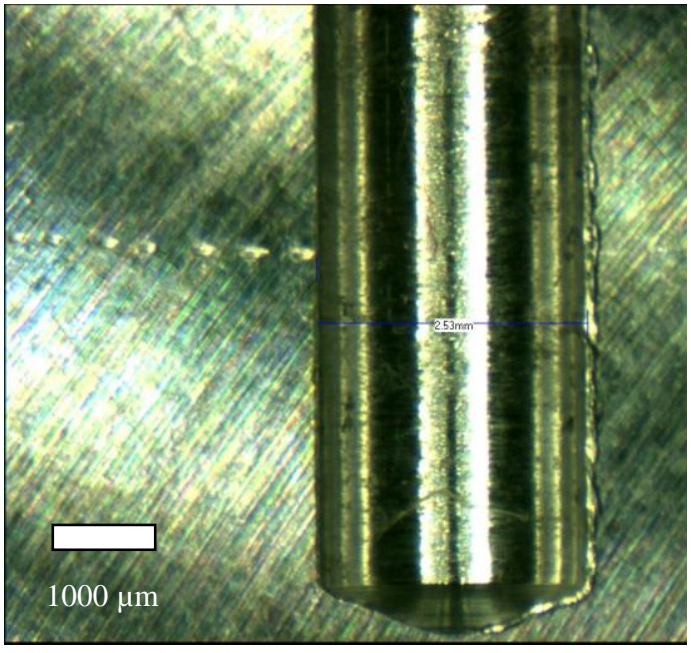

Figure 2 The lowest surface roughness specimen number 2

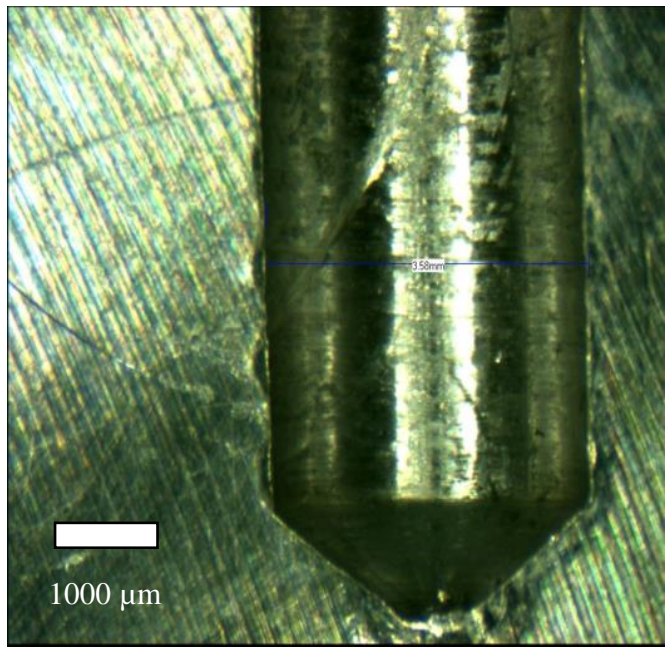

Figure 3 The highest surface roughness specimen number 9

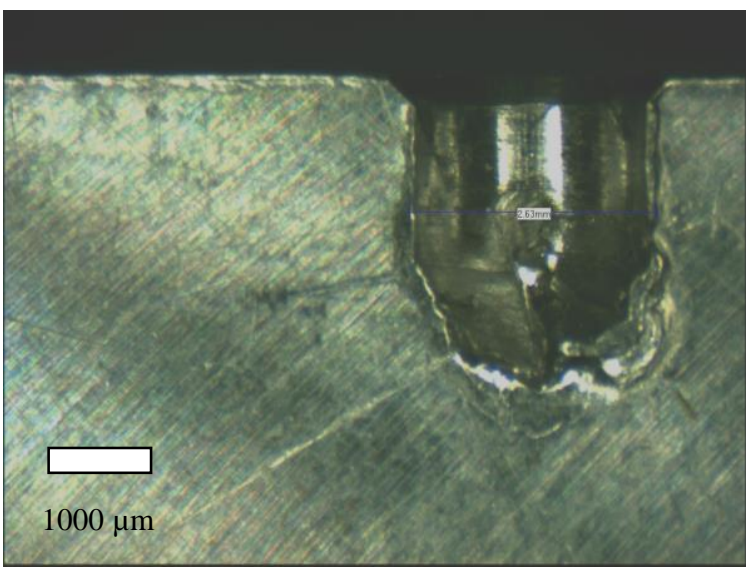

Figure 4 Observation appearance of specimen number 3 


\subsection{Analysis of Variance (ANOVA)}

The ANOVA analysis for the quadratic model is shown in Table 4. The "Model F-value" of 2.26 implies the model is not significant relative to the noise. There is an $11.99 \%$ chance that a "Model F-value" this large could occur due to noise. This implies that the model does not represent the data within the required $95 \%$ confidence interval.

To improve the model, a cubic term $\mathrm{ABC}$ and $\mathrm{BC}^{2}$ is added to the model and the ANOVA analysis Reduced Cubic Model is shown in Table 5. The Model F-value of 4.46 implies the model is significant. There is only a $2.90 \%$ chance that a "Model F-Value" this large could occur due to noise. The "Lack of Fit F-value" of 173.90 implies the Lack of Fit is significant. There is only a $0.01 \%$ chance that a "Lack of Fit F-value" this large could occur due to noise. Through this model reduce, the value of $\mathrm{R}$ squared is 0.8751 and standard deviation is 0.25 . The $\mathrm{R}$ squared is high and almost reaching value 1 , thus indicating that it is desirable.

From ANOVA analysis of the reduced cubic model, the significant factors that influence the surface roughness indicated by "p-value" less than 0.05 . In this case A, C, B2, C2, AB, AC and $\mathrm{BC}$ are significant model terms. It shows that, there are interactions between parameters. Although the interaction between $\mathrm{BC}^{2}$ and $\mathrm{ABC}$ is less than 0.05 , the interaction cannot be ascertained due to the aliased nature of cubic term for this particular set-up.

\subsection{Mathematical Model}

Equation 1 shows the mathematical relationship for correlating the surface roughness considering output responses of drilling parameters, i.e. spindle speed, feed rate and drill diameter. The mathematical model was obtained from using design expert software. Equation 2 shows the example of calculation using equation 1 for trial number 1 . For trial number 1 , the combination of spindle speed, feed rate and drill diameter are $270 \mathrm{rpm}, 78 \mathrm{~mm} / \mathrm{min}$ and $2.5 \mathrm{~mm}$ respectively. Equation 3 shows the differences between calculation using equation 1 and experimental result for trial number 1 .

Surface Roughness $=-10.193+1.677 \times 10^{-4} * \mathrm{~A}+0.0912 * \mathrm{~B}+$ $6.343 * \mathrm{C}+2.53 \times 10^{-7} * \mathrm{~A}^{2}+2.929 \times 10^{-5} * \mathrm{~B}^{2}-0.771 * \mathrm{C}^{2}-$ $2.128 \times 10^{-5} * \mathrm{~A} * \mathrm{~B}-1.095 \times 10^{-4} * \mathrm{~A} * \mathrm{C}-0.042 * \mathrm{~B} * \mathrm{C}+$ $4.313 \times 10^{-3} * \mathrm{~B} * \mathrm{C}^{2}+4.211 \times 10^{-6} * \mathrm{~A} * \mathrm{~B} * \mathrm{C}$

Surface Roughness $=-10.193+1.677 \times 10^{-4} *(270)+0.0912 *$ $(78)+6.343 *(2.5)+2.53 \times 10^{-7} *(270)^{2}+2.929 \times 10^{-5} *(78)^{2}-$ $0.771 *(2.5)^{2}-2.128 \times 10^{-5} *(270) *(78)-1.095 \times 10^{-4} *(270) *$ $(2.5)-0.042 *(78) *(2.5)+4.313 \times 10^{-3} *(78) *(2.5)^{2}+$ $4.211 \times 10^{-6} *(270) *(78) *(2.5)$

Surface Roughness $=1.86$

Difference $=\frac{R_{a} \exp .-R_{a} \text { cal }}{R_{a} \exp } \times 100$

The differential between minimum and maximum of experimental and calculated is $0 \%$ and $29 \%$ respectively as shown in Table 6. Correlation between the experimental surface roughness is parallel to the mathematical model. The value predicted nearly data obtain from experimental.

Table 4 ANOVA analysis of the quadratic model for surface roughness

\begin{tabular}{ccccccc}
\hline \multicolumn{6}{c}{ ANOVA for Response Surface Quadratic Model } & \\
Source & $\begin{array}{c}\text { Sum of } \\
\text { Square }\end{array}$ & DF & $\begin{array}{c}\text { Mean } \\
\text { Square }\end{array}$ & F value & $\begin{array}{c}\text { Prob. } \\
>\text { F }\end{array}$ & \\
\hline Model & 2.409 & 9 & 0.268 & 2.26 & 0.1199 & $\begin{array}{c}\text { Not } \\
\text { significant }\end{array}$ \\
A & 0.496 & 1 & 0.496 & 4.188 & 0.071 & \\
B & 0.001 & 1 & 0.001 & 0.007 & 0.9362 & \\
C & 0.797 & 1 & 0.797 & 6.736 & 0.029 & \\
$\mathrm{~A}^{2}$ & 0.007 & 1 & 0.007 & 0.055 & 0.8193 \\
$\mathrm{~B}^{2}$ & 0.22 & 1 & 0.22 & 1.857 & 0.2061 & \\
$\mathrm{C}^{2}$ & 0.501 & 1 & 0.501 & 4.232 & 0.0698 & \\
AB & 0.09 & 1 & 0.09 & 0.762 & 0.4054 & \\
AC & 0.743 & 1 & 0.743 & 6.284 & 0.0335 & \\
BC & 0.286 & 1 & 0.286 & 2.413 & 0.1547 & \\
Residual & 1.065 & 9 & 0.118 & & \\
Lack of & 1.059 & 4 & 0.265 & 215.159 & $<$ \\
Fit & 0.006 & 5 & 0.001 & & 0.0001 & \\
Pure Error & 3.473 & 18 & & & \\
Correction & & & & & \\
\hline
\end{tabular}


Table 5 ANOVA analysis of response surface reduce model for surface roughness

\begin{tabular}{ccccccc}
\hline \multicolumn{6}{c}{ ANOVA for Response Surface Quadratic Model } & \\
Source & $\begin{array}{c}\text { Sum of } \\
\text { Square }\end{array}$ & DF & $\begin{array}{c}\text { Mean } \\
\text { Square }\end{array}$ & F value & $\begin{array}{c}\text { Prob. } \\
>\text { F }\end{array}$ & \\
\hline Model & 3.039 & 11 & 0.2763 & 4.46 & 0.029 & Significant \\
A & 1.048 & 1 & 1.0477 & 16.901 & 0.0023 & \\
B & 0.16 & 1 & 0.1596 & 2.574 & 0.1527 & \\
C & 1.345 & 1 & 1.3451 & 21.697 & 0.0045 & \\
A $^{2}$ & 0.205 & 1 & 0.2047 & 3.302 & 0.112 & \\
$B^{2}$ & 0.372 & 1 & 0.3715 & 5.993 & 0.0442 & \\
C $^{2}$ & 0.379 & 1 & 0.379 & 6.114 & 0.0427 & \\
AB & 0.487 & 1 & 0.4868 & 7.853 & 0.0264 & \\
AC & 1.337 & 1 & 1.3366 & 21.56 & 0.0024 & \\
BC & 0.825 & 1 & 0.8247 & 13.303 & 0.0082 & \\
Residual & 0.468 & 1 & 0.468 & 7.55 & 0.0286 & \\
Lack of & 0.447 & 1 & 0.4467 & 7.206 & 0.0313 & \\
Fit & 0.434 & 7 & 0.062 & & \\
Pure Error & 0.428 & 2 & 0.2139 & 173.902 & $<$ \\
Correction & & & & & 0.0001 & \\
\hline
\end{tabular}

Table 6 Percentage differences between experimental and calculation

\begin{tabular}{cccc}
\hline Std & $\boldsymbol{R}_{\boldsymbol{a}}$ exp. & $\boldsymbol{R}_{\boldsymbol{a}}$ cal & Differences \\
\hline 1 & 1.86 & 1.86 & $0 \%$ \\
2 & 1.06 & 1.22 & $-15 \%$ \\
3 & $\mathrm{~TB}$ & 4.83 & - \\
4 & 1.24 & 1.4 & $-13 \%$ \\
5 & 1.42 & 1.51 & $-7 \%$ \\
6 & 1.62 & 1.82 & $-12 \%$ \\
7 & 1.17 & 1.26 & $-8 \%$ \\
8 & 1.31 & 1.51 & $-15 \%$ \\
9 & 2.59 & 2.59 & $0 \%$ \\
10 & 1.74 & 1.42 & $18 \%$ \\
11 & 2.56 & 2.4 & $6 \%$ \\
12 & 2.33 & 2.17 & $7 \%$ \\
13 & 1.97 & 1.91 & $3 \%$ \\
14 & 1.19 & 0.85 & $29 \%$ \\
15 & 1.82 & 1.82 & $0 \%$ \\
16 & 1.8 & 1.82 & $-1 \%$ \\
17 & 1.79 & 1.82 & $-2 \%$ \\
18 & 1.8 & 1.82 & $-1 \%$ \\
19 & 1.83 & 1.82 & $1 \%$ \\
20 & 1.73 & 1.82 & \\
\hline
\end{tabular}




\subsection{CONCLUSION}

In this study, the effect of drilling parameters on surface roughness of drilling hole using RSM was studied. From the result, the minimum of surface roughness is $1.06 \mu \mathrm{m}$ having combinations of higher spindle speed with lower feed rate and smaller drill diameter. Meanwhile the maximum of surface roughness is $2.59 \mu \mathrm{m}$ having combination lower spindle speed with higher feed rate and bigger drill diameter. Besides that, for the specimen number 3 , the surface roughness value cannot be measured. This is because of the tool was broken. It is shown that, the combination between spindle speed, feed rate and drill diameter for specimen 3 is inappropriate if using lower spindle speed with combination higher feed rate and smaller drill diameter. Further, from ANOVA analysis, the most parameters that affect surface roughness are spindle speed and drill diameter. Furthermore, there are interactions among each parameter that it can be seen from development of a mathematical model between each parameter on surface roughness. The differential between minimum and maximum of experimental and calculated is $0 \%$ and $29 \%$.

\section{Acknowledgement}

The authors wish to thank Universiti Teknikal Malaysia Melaka and the Government of Malaysia for technical and financial support for this experiment.

\section{References}

[1] R. Rajput. 2007. Comprehensive Manufacturing Practice. Firewall Media. 159.

[2] A. Faridi. 2013. Driling. [Online]. Available: http://www.scribd.com/doc/4373001/Drilling-Process. [Accessed: 10Dec-2013].
[3] S. Kalpakjian and S. Schmid. 2013. Manufacturing Engineering \& Technology. 7th ed. Pearson Education.

[4] V. S. Udayvaran Konada. 2007. A Novel Approach to Predict Surface Roughness in Machining Operations Using Fuzzy Set Theory. ProQuest. 12.

[5] M. Hadzley, A. S. Sarah, R. Izamshah, M. Amran, M. Shahir, M. Amri, N. Fatin, M. Raffi. 2014. Evaluation of the Surface Integrity when Machining LM6 Aluminum Metal Matrix Composites Using Coated and Uncoated Carbide Cutting Tools. Appl. Mech. \& Mat. 465: 10491053.

[6] M. S. Kassim, C. H. Che Haron, J. A. Ghani, M. A. Sulaiman. 2013. Prediction Surface Roughness in High-Speed Milling of Inconel 718 under MQL Using RSM Method. Middle East J. of Sci. Res. 13(3): 264-272.

[7] P. Sahoo, B. Tapan, and J. Paulo Davim. 2011. Fractal Analysis in Machining. Springer. 21.

[8] S. Sharma, A. Malik, and S. Satya. 2009. Application of Response Surface Methodology (RSM) for optimization Of Nutrient Supplementation for $\mathrm{Cr}$ (VI) Removal by Aspergillus Lentulus AML05. J. Hazard. Mater. 164(2-3): 1198-204.

[9] N. S. Mohan, A. Ramachandra, and S. M. Kulkarni. 2005. Influence of Process Parameters on Cutting Force and Torque During Drilling of Glass-Fiber Polyester Reinforced Composites. Compos. Struct. 71(34): 407-413.

[10] U. A. Khashaba, M. A. Seif, and M. A. Elhamid. 2007. Drilling Analysis of Chopped Composites. Compos. Part A Appl. Sci. Manuf. 38(1): 61-70.

[11] C. Tsao and H. Hocheng. 2004. Taguchi Analysis of Delamination Associated With Various Drill Bits In Drilling Of Composite Material. Int. J. Mach. Tools Manuf. 44(10): 1085-1090.

[12] B. S. Rao, R. Rudramoorthy, S. Srinivas, and B. N. Rao. 2008. Effect of Drilling Induced Damage on Notched Tensile and Pin Bearing Strengths of Woven GFR-epoxy Composites. Mater. Sci. Eng. A. 472(1-2): 347-352

[13] E. Kilickap. 2010. Optimization of cutting Parameters on Delamination Based on Taguchi Method During Drilling of GFRP Composite. Expert Syst. Appl. 37(8): 6116-6122.

[14] G. C. Onwubolu and S. Kumar. 2006. Response Surface Methodologybased Approach to CNC Drilling Operations. J. Mater. Process. Technol. 171(1): 41-47.

[15] M. N. Abd Rahman. 2009. Modelling of Physical Vapour Deposition (PVD) Process on Cutting Tool Using Response Surface Methodology (RSM). PhD. Thesis, Coventry University. 